\title{
Sodium hydroxide enhances extractability and analysis of proanthocyanidins in ensiled sainfoin (onobrychis viciifolia)
}

Article

Accepted Version

Ramsay, A., Drake, C., Grosse Brinkhaus, A., Girard, M., Copani, G., Dohme-Meier, F., Bee, G., Niderkorn, V. and Mueller-Harvey, I. (2015) Sodium hydroxide enhances extractability and analysis of proanthocyanidins in ensiled sainfoin (onobrychis viciifolia). Journal of Agricultural and Food Chemistry, 63 (43). pp. 9471-9479. ISSN 1520-5118 doi: https://doi.org/10.1021/acs.jafc.5b04106 Available at https://centaur.reading.ac.uk/46385/

It is advisable to refer to the publisher's version if you intend to cite from the work. See Guidance on citing.

To link to this article DOI: http://dx.doi.org/10.1021/acs.jafc.5b04106

Publisher: American Chemical Society

All outputs in CentAUR are protected by Intellectual Property Rights law, including copyright law. Copyright and IPR is retained by the creators or other copyright holders. Terms and conditions for use of this material are defined in the End User Agreement. 


\section{CentAUR}

Central Archive at the University of Reading

Reading's research outputs online 


\section{Sodium Hydroxide Enhances Extractability and Analysis of Proanthocyanidins in Ensiled Sainfoin (Onobrychis viciifolia)}

Aina Ramsay ${ }^{\dagger *}$, Chris Drake ${ }^{\dagger}$, Anja Grosse Brinkhaus ${ }^{\ddagger}$, Marion Girard ${ }^{\ddagger}$, Giuseppe Copani§, Frigga Dohme-Meier ${ }^{\ddagger}$, Giuseppe Bee ${ }^{\ddagger}$ Vincent Niderkorn ${ }^{\S}$, Irene MuellerHarvey $^{\dagger}$

${ }^{\dagger}$ Chemistry and Biochemistry Laboratory, School of Agriculture, Policy and Development, University of Reading, 1 Early Gate, P.O. Box 236, Reading RG6 6AT, UK

Agroscope, Institute for Livestock Sciences, Route de la Tioleyre 4, 1725 Posieux, Switzerland.

§ INRA, UMR 1213 Herbivores, F-63122 Saint-Genès-Champanelle, France.

*Corresponding author (Tel: +44 (0)118 378 6619; Fax: +44 (0)118 935 2421; Email: aina.ramsay@hotmail.fr and aina.ramsay@reading.ac.uk) 
1 ABSTRACT: Little information exists on the effects of ensiling on condensed tannins

2 or proanthocyanidins. The acetone-butanol- $\mathrm{HCl}$ assay is suitable for measuring

3 proanthocyanidin contents in a wide range of samples, silages included, but provides

4 limited information on proanthocyanidin composition, which is of interest for

5 deciphering the relationships between tannins and their bioactivities in terms of

6 animal nutrition or health. Degradation with benzyl mercaptan (thiolysis) provides

7 information on proanthocyanidin composition but proanthocyanidins in several

8 sainfoin silages have proved resistant to thiolysis. We now report that a pre-

9 treatment step with sodium hydroxide prior to thiolysis was needed to enable their

10 analysis. This alkaline treatment increased their extractability from ensiled sainfoin

11 and facilitated especially the release of larger proanthocyanidins. Ensiling reduced assayable proanthocyanidins by $29 \%$ but the composition of the remaining proanthocyanidins in silage resembled those of the fresh plants.

KEYWORDS: silage, thiolysis, unextractable tannins, alkaline pre-treatment, reaction products 


\section{INTRODUCTION}

24 Sainfoin (Onobrychis viciifolia) is a perennial forage legume that grows in parts of

Europe, the U.S. and Canada. ${ }^{1}$ Ruminant animals generate safer forms of environmental nitrogen emissions on sainfoin diets, ${ }^{2}$ can safely graze it as it is nonbloating $^{1}$ and suffer lower intestinal parasite burdens. ${ }^{3,4}$ These health and environmental benefits have been attributed to its proanthocyanidins (Figure 1). ${ }^{5}$ Sainfoin is suitable for processing into silage, which provides energy and protein during periods of feed shortages. ${ }^{6}$ It has, however, also been shown that preservation, such as ensiling, lowers proanthocyanidin extractability in different forage legumes. ${ }^{5,7}$

Currently, there is no information on the effects of ensiling on proanthocyanidin composition. Few methods exist for analyzing tannins in fermented samples and the $\mathrm{HCl}$-butanol method is currently the most widely used method for silages ${ }^{6,8,9}$ but provides only limited information on proanthocyanidin structures. In contrast, the milder acid-catalyzed degradation of proanthocyanidins with benzyl mercaptan (i.e. thiolysis) yields quantitative data on the composition of flavan-3-ols in extension and terminal units and enables calculation of the mean degree of polymerization of the proanthocyanidins. ${ }^{10}$ Surprisingly, however, although proanthocyanidins can be quantitated by the $\mathrm{HCl}$-butanol assay in silages, ${ }^{11,12}$ thiolysis ${ }^{10}$ with benzyl mercaptan at $40{ }^{\circ} \mathrm{C}$ did not detect any proanthocyanidins in several silages.

There is some evidence that the decrease of extractable proanthocyanidins in sainfoin and other plants after ensiling is caused by the binding of proanthocyanidins to protein and fiber..$^{5,7,11}$ Recently, White et al. ${ }^{13}$ reported that alkaline hydrolysis with $\mathrm{NaOH}$ improved the extraction of A-type procyanidins from cranberry pomace and 
bound phenolics. ${ }^{14,15}$ Therefore, the present study evaluated whether pre-treatment with $\mathrm{NaOH}$ would enable compositional analysis of proanthocyanidins in ensiled sainfoin by thiolytic degradation with benzyl mercaptan.

\section{MATERIALS AND METHODS}

Chemicals. Hydrochloric acid (concentrated, 36\%), acetone (analytical reagent grade), dichloromethane (HPLC grade) and acetonitrile (HPLC grade) were purchased from ThermoFisher Scientific Ltd (Loughborough, U.K.); ( \pm )-taxifolin (98\%) from Apin Chemicals (Abingdon, U.K.); benzyl mercaptan (98\%), catechin (3), epicatechin (4), gallocatechin (1), epigallocatechin (2), quercetin (95\%), kaempferol (98\%), gallic acid and 3,4-dihydroxybenzoic acid from Sigma-Aldrich (Poole, U.K.); rutin (98\%) from Lancaster Synthesis (Lancaster, UK) and formononetin (98\%) from Acros Organics (Loughborough, UK). Deionized water was obtained from a Milli-Q System (Millipore, Watford, U.K.). Quercetin, kaempferol and formononetin were dissolved in methanol/water $(1: 1, v / v)$ using six concentrations $(n=2)$ and peak areas were used for the calibration curve.

Plant Materials. Sainfoin (Onobrychis viciifolia 'Perly') was sown at the Swiss Federal Research Station ALP (Posieux, altitude: 650 m) in April 2012 and harvested at the early flowering stage on 9 July 2012. A bulked sample $(5 \mathrm{~kg})$ was freeze-dried (= fresh/freeze-dried sample) and had a dry matter (DM) content of $169.4 \mathrm{~g} / \mathrm{kg}$ fresh material and an organic matter (OM) content of $923.2 \mathrm{~g} / \mathrm{kg} \mathrm{DM}$. The samples were wilted for $24 \mathrm{~h}$ in the field in a swath to minimize leaf loss and then chopped $(1-2 \mathrm{~cm})$ with a Mex GT chaff cutter (Poettinger, Grieskirchen, Austria). The wilted samples (DM content was $377.9 \mathrm{~g} / \mathrm{kg}$ fresh wet material; OM content was $913.2 \mathrm{~g} / \mathrm{kg} \mathrm{DM}$ ) 
were ensiled without additives in $30 \mathrm{~L}$ barrels. The barrels were filled, compressed by hand and stored at room temperature in a dark room for $86 \mathrm{~d}$. The room was neither cooled nor heated in the barn facilities (without insulation). The room temperature was recorded every week and ranged from $23.0^{\circ} \mathrm{C}$ (August) to $17.7^{\circ} \mathrm{C}$ (October). On average it was $20.4^{\circ} \mathrm{C}$. On opening the silo after 86 days of ensiling, the $\mathrm{pH}$ was $4.51 \pm 0.03$, the concentrations of short chain volatile fatty acids were $6.72 \pm 0.94(\mathrm{mg} / \mathrm{kg} \mathrm{DM})$ for acetate, $56.9 \pm 5.96(\mathrm{mg} / \mathrm{kg} \mathrm{DM})$ for lactate and $1.02 \pm$ $0.06(\mathrm{mg} / \mathrm{kg} \mathrm{DM})$ for butyrate. The silage was mixed by hand in a tray, subsamples were taken, freeze-dried, ground to pass a $<1 \mathrm{~mm}$ screen sieve with an impeller SM1 cutting mill (Retsch, Haan, Germany) and stored at room temperature. The silage DM content was $370.7 \mathrm{~g} / \mathrm{kg}$, and the OM content was $911.3 \mathrm{~g} / \mathrm{kg}$ DM. Three other sainfoin silage samples (SF1 to SF3, field replicates) were prepared in INRA Theix (France) according to Copani et al. ${ }^{9}$

\section{Preparation of a Purified Proanthocyanidin Fraction and Acetone-Water}

Extracts. A purified proanthocyanidin fraction was isolated for use as a proanthocyanidin standard in the acetone-butanol- $\mathrm{HCl}$ assay ${ }^{16}$ and also for the proanthocyanidin degradation test with $\mathrm{NaOH}$. Sainfoin 'Cotswold Common' was harvested on 24 July 2007 from Hartley Farm near Seven Springs (Cheltenham, Gloucestershire, U.K.), manually separated from weeds, and freeze-dried. It was ground using a impeller SM1 cutting mill (Retsch, Haan, Germany) to pass $<8 \mathrm{~mm}$ and then ground again to $<1 \mathrm{~mm}$. The ground sainfoin $(20 \mathrm{~g})$ was extracted with acetone/water $(7: 3, \mathrm{v} / \mathrm{v} ; 250 \mathrm{~mL}, 1 \mathrm{~h})$. Acetone was removed under vacuum and the aqueous phase was loaded on a Sephadex LH-20 column. The column was rinsed, firstly with water, and then with acetone/water (3:7), and the proanthocyanidin 
fraction was eluted with acetone/water $(1: 1, \mathrm{v} / \mathrm{v})$. Thiolysis ${ }^{10}$ coupled to HPLC-MS revealed that this fraction had a very high proanthocyanidin content $(98 \mathrm{~g} / 100 \mathrm{~g}$ fraction) with an mean degree of polymerization value of 9.7 , a procyanidin/prodelphinidin ratio of $44.1 / 55.9$ and a cis/trans flavan-3-ol ratio of 81.9/18.1.

In addition, separate extracts were prepared from the fresh/freeze-dried and ensiled sainfoin samples $(5 \mathrm{~g})$ from Posieux with acetone/water $(7: 3, \mathrm{v} / \mathrm{v} ; 63 \mathrm{~mL}, 1 \mathrm{~h})$ as previously described. ${ }^{10}$ The residues remaining after this acetone-water extraction were also kept for proanthocyanidin analysis (= solvent-extracted residue).

\section{Thiolysis of the Purified Proanthocyanidin Fraction, Acetone/Water Extracts} and Solvent-Extracted Residues. The purified proanthocyanidin fraction (8 mg), acetone-water extracts and plant residues that remained after the acetone-water extraction $(8 \mathrm{mg}$ ) were placed into a $100 \mathrm{~mm} \times 16 \mathrm{~mm}$ screw cap glass tube (Fisher Scientific, Loughborough, U.K.) with a stirring magnet $(10 \times 5 \times 5 \mathrm{~mm})$. Methanol (1.5 $\mathrm{mL}$ ) was added followed by methanol acidified with concentrated $\mathrm{HCl}(3.3 \% ; 500 \mu \mathrm{L})$ and benzyl mercaptan $(50 \mu \mathrm{L})$. Tubes were capped and placed into a water bath at $40{ }^{\circ} \mathrm{C}$ for $1 \mathrm{~h}$ under vigorous stirring. ${ }^{10}$ The reaction was stopped by placing the tube in an ice bath for $5 \mathrm{~min}$. Distilled water $(2.5 \mathrm{~mL})$ and the internal standard, taxifolin in methanol (500 $\mu \mathrm{L} ; 0.1 \mathrm{mg} / \mathrm{mL})$, were added and thoroughly mixed. The mixture was transferred into a vial $(800 \mu \mathrm{L})$, closed with a crimp top and analyzed by HPLC-MS within $24 \mathrm{~h}$.

\section{Sodium Hydroxide Pre-Treatment of Plant Samples and Solvent-Extracted}

Residues. Fresh/freeze-dried sainfoin, ensiled sainfoin or acetone-water extracted 
plant residues $(150 \mathrm{mg})$ were placed into a screw cap tube containing a stirring magnet. Air was replaced with argon before adding aqueous $\mathrm{NaOH}(0.5,1,2,3,4 \mathrm{M}$; $2 \mathrm{~mL}$ ). The tube was flushed once more with argon just before capping, placed into a water bath at $40{ }^{\circ} \mathrm{C}$ and stirred for $5,15,30,60 \mathrm{~min}$ at $1500 \mathrm{rpm}$. The tube was cooled for $2 \mathrm{~min}$ in an ice bath, the solution was neutralized with $4 \mathrm{M} \mathrm{HCl}$, stirred, distilled water $(1 \mathrm{~mL})$ was added and the tube was left stirring to cool for another 2 min. The sample was centrifuged at $3000 \mathrm{rpm}$ for $1 \mathrm{~min}$, frozen and freeze-dried before thiolysis.

In Planta Thiolysis. The original untreated and $\mathrm{NaOH}$ treated samples $(150 \mathrm{mg})$, which were the freeze-dried sainfoin sample from Posieux, the ensiled sainfoin samples from Posieux and Theix and the acetone-water solvent extracted residues from the Posieux samples, were reacted with the thiolysis reagent $(2 \mathrm{~mL}$ methanol, 1 $\mathrm{mL}$ of $3.3 \% \mathrm{HCl}$ in methanol, and $100 \mu \mathrm{L}$ benzyl mercaptan). The tubes were capped immediately and placed in a water bath at $40^{\circ} \mathrm{C}$ for $1 \mathrm{~h}$ under vigorous stirring. The reaction was stopped by placing the tubes in an ice bath for $5 \mathrm{~min}$. The samples were centrifuged at $3000 \mathrm{rpm}$ for $3 \mathrm{~min}$, and supernatants $(1 \mathrm{~mL})$ were transferred to clean screw cap glass tubes. Distilled water $(4 \mathrm{~mL})$ was added to the supernatants with the internal standard, taxifolin in methanol $(500 \mu \mathrm{L} ; 0.1 \mathrm{mg} / \mathrm{mL})$. The tubes were capped, shaken, and analyzed by HPLC-MS within $24 \mathrm{~h}$.

HPLC-MS Analysis. Flavan-3-ols and their benzyl mercaptan-adducts were identified by HPLC-MS analysis on an Agilent 1100 Series HPLC system and an API-ES Hewlett Packard 1100 MSD detector (Agilent Technologies, Waldbronn, Germany). Samples $(20 \mu \mathrm{L})$ were injected into the HPLC at room temperature and 
the column used was a $250 \mathrm{~mm} \times 4.6 \mathrm{~mm}$ i.d., $3 \mu \mathrm{m}$, ACE $\mathrm{C}_{18}$ column with a $10 \mathrm{~mm}$ x $4.6 \mathrm{~mm}$ i.d. guard cartridge of the same material (Hichrom Ltd, Theale, U.K.). The HPLC system consisted of a G1379A degasser, G1312A binary pump, a G1313A ALS autoinjector and a G1314A VWD UV detector. Data were acquired with ChemStation software (version A 10.01 Rev. B.01.03). The flow rate was 0.75 $\mathrm{mL} / \mathrm{min}$ using $1 \%$ acetic acid in water (solvent A) and HPLC-grade acetonitrile (solvent B). The following gradient was employed: 0-35 min, 0-36\% B; 35-40 min, $36-50 \%$ B; $40-45$ min, 50-100\% B; 45-55 min, 100-0\% B; 55-60 min, 0\% B. Eluting compounds were recorded at $280 \mathrm{~nm}$. Mass spectra were recorded in the negative ionization scan mode from $\mathrm{m} / \mathrm{z} 100-1000$ using the following conditions: capillary voltage, -3000 V; nebulizer gas pressure, 35 psi; drying gas, $12 \mathrm{~mL} / \mathrm{min}$; and dry heater temperature, $350{ }^{\circ} \mathrm{C}$. Flavan-3-ol terminal and extension units were procyanidin and prodelphinidin tannins and cis- and trans flavan-3-ols. ${ }^{10}$ 
proanthocyanidin fraction described above was used as standard for the calibration curve.

Statistical Analysis. The proanthocyanidin parameters (content, mean degree of polymerization, \% prodelphinidin, \% cis-flavanols) were subjected to a two-way analysis of variance (ANOVA) performed with repeated measures analysis to test the effect of $\mathrm{NaOH}$ concentration and reaction time. All analyses were determined by protected LSD $(\alpha=0.01)$.

\section{RESULTS AND DISCUSSION}

\section{Optimization of Alkaline Pre-treatment for Ensiled Sainfoin. Several $\mathrm{NaOH}$}

concentrations, temperatures and reaction times were tested initially. These trials showed that low $\mathrm{NaOH}$ concentrations $(0.05$ and $0.1 \mathrm{M})$ did not improve proanthocyanidin detection after thiolysis and reactions at $60{ }^{\circ} \mathrm{C}$ induced considerable proanthocyanidin degradation (data not shown). These $\mathrm{NaOH}$ studies were repeated several times over the course of three months and generated similar results. All of these initial studies were conducted under nitrogen and produced rather large standard deviations that were successfully reduced once the $\mathrm{NaOH}$ reaction was performed under argon. Subsequent experiments, therefore, explored $0.5,1,2,3$ and $4 \mathrm{M} \mathrm{NaOH}$ concentrations and 5, 15, 30, 60 min reaction times at 40 ${ }^{\circ} \mathrm{C}$ under argon. Time $(P<0.001)$ and $\mathrm{NaOH}$ concentration $(P<0.001$ to 0.008$)$ had a significant effect on the thiolysis results in terms of proanthocyanidin content, mean degree of polymerization, percentages of prodelphinidins and cis flavan-3-ols within proanthocyanidins. The mean degree of polymerization was also significantly $(\mathrm{P}<$ 
0.001 ) affected by a time $\times \mathrm{NaOH}$ concentration interaction. Overall, the length of the reaction time had the greatest effect on all parameters followed by $\mathrm{NaOH}$ concentration.

The highest proanthocyanidin content $(2.17 \mathrm{~g} / 100 \mathrm{~g}$ dry weight; $\mathrm{cv}=4.3 \%)$ was obtained with $1 \mathrm{M} \mathrm{NaOH}$ and a 15 min reaction time. The mean degree of polymerization was relatively stable at $0.5,1$ and $2 \mathrm{M} \mathrm{NaOH}$; and a value of 9.1 , with the $1 \mathrm{M} \mathrm{NaOH}$ and 15 min pre-treatment, was comparable to 8.2 in the fresh sainfoin (Table 1). The percentage of prodelphinidins remained stable between 15 and 60 min with 1 and $2 \mathrm{M} \mathrm{NaOH}$, and the percentage of trans flavan-3-ols increased only slightly over $60 \mathrm{~min}$.

A closer look at the flavan-3-ol composition revealed that more terminal catechin (3) and especially epigallocatechin (2) units were detectable with the lowest $\mathrm{NaOH}$ concentrations $(0.5$ and $1 \mathrm{M})$ and 15 and 30 min reaction times (Table 2). The epicatechin (4) concentration from the $1 \mathrm{M} \mathrm{NaOH}$ reaction was low, but remained constant over time and produced consistently small errors in contrast to the 0.5 and $2 \mathrm{M} \mathrm{NaOH}$ treatments. The highest extension unit concentrations of gallocatechin (1), epigallocatechin (2) and epicatechin (4) were obtained with $1 \mathrm{M} \mathrm{NaOH}$ and 5 or 15 min reaction times. However, the differences were not significant and standard errors were generally smaller at 15 min compared to 5 or 60 min. Thus, we chose the $1 \mathrm{M} \mathrm{NaOH}$ and 15 min pre-treatment because this gave the highest proanthocyanidin content based on a maximal release of epigallocatechin (2), epicatechin (4) and gallocatechin (1) units, the most stable mean degree of polymerization and consistently low standard errors. Longer hydrolysis times and especially higher $\mathrm{NaOH}$ concentrations (2 to $4 \mathrm{M}$ ) led to lower mean degrees of 
polymerization, which suggested either proanthocyanidin depolymerization or degradation as observed previously. ${ }^{13}$

Effect of $\mathrm{NaOH}$ on Purified Tannins. Next, the effects of the optimized $\mathrm{NaOH}$ reaction conditions were tested on a purified sainfoin proanthocyanidin fraction in order to identify marker compounds that might be indicative of any proanthocyanidin-derived degradation products from the $\mathrm{NaOH}$ reaction when applied directly to silage samples. HPLC chromatograms before and after $\mathrm{NaOH}$ pretreatment are shown in Figure 2. Flavan-3-ol terminal units (peaks 1 to 4) and extension units (peaks 6 to 11) are still visible after 15 min (Figure 2B) but start to disappear after $60 \mathrm{~min}$ (Figure 2C). These chromatograms revealed a rapid loss of proanthocyanidins (from $100 \mathrm{~g}$ to less than $20 \mathrm{~g} / 100 \mathrm{~g}$ fraction) and a change in the mean degree of polymerization from 9.7 to less than 6 within $5 \mathrm{~min}$. The most noticeable effect was the appearance of a 'hump', which is likely to stem from oxidized or polymerized proanthocyanidins and suggested that many more reaction products were formed over time during $\mathrm{NaOH}$ treatment. ${ }^{17}$

Several of the degradation products (peaks a to g, Figure 2) were tentatively assigned based on their $m / z$-values and literature reports: peak a with an $m / z$ value of $169.2(R T=13.96 \mathrm{~min})$ could stem from gallic acid and peak $\mathrm{c}$ with an $\mathrm{m} / \mathrm{z}$ of $153.2(\mathrm{RT}=19.57 \mathrm{~min})$ from 3,4-dihydroxybenzoic acid as these are typical products from base-catalyzed/degradation reaction of the B-rings of prodelphinidins and procyanidins, respectively. ${ }^{18}$ Other plausible proanthocyanidin oxidation/degradation products are peaks $b$ and $d$ with $\mathrm{m} / z$ values of $303.3(R T=14.31 \mathrm{~min})$ and $319.2(R T$ $=24.05 \mathrm{~min}$ ), respectively, which might be $\alpha$-ketoretro-chalcones derived from base-catalyzed opening of the C-ring of catechin (3) or epicatechin (4) moieties in 
procyanidins and gallocatechin (1) or epigallocatechin (2) moieties in prodelphinidins followed by the cleavage of the interflavanyl bond under base-catalysis. ${ }^{18,19}$ Peak e ( $\mathrm{m} / \mathrm{z}$ of 309.2 ; RT $31.87 \mathrm{~min}$ ) could have come from an epigallocatechin (2) oxidation product as reported after $\mathrm{H}_{2} \mathrm{O}_{2}$ treatment; ${ }^{20}$ peak $\mathrm{g}(\mathrm{m} / \mathrm{z}$ of $427.3 ; \mathrm{RT}=47.75 \mathrm{~min})$ from theacitrinin $A ;{ }^{19}$ and peak $f(m / z$ of $310.2 ; R T=45.29 \mathrm{~min})$ could be the rearranged benzylsulfanyl indan derivative of catechinic acid. ${ }^{18}$

NaOH Pre-Treatment for in Planta Analysis of Proanthocyanidins in Ensiled

Sainfoin. Although $\mathrm{NaOH}$ generated several degradation products from the pure proanthocyanidins (Figures 2B and C), none of these products nor the polymeric hump were seen when ensiled samples were treated with $\mathrm{NaOH}$ (Figure 3). In contrast to the $\mathrm{NaOH}$-treated pure proanthocyanidin fraction, all flavan-3-ol terminal and extension units were clearly detectable in the treated silage (peaks labelled 2 to 4 and 7 to 11 ; Figure 3B).

Without the $\mathrm{NaOH}$ treatment, direct thiolysis of the plant materials yielded 3.1 and $0.4 \mathrm{~g}$ proanthocyanidins/100 $\mathrm{g}$ dry weight for fresh and ensiled samples, respectively (Table 1). In comparison, the acetone-butanol- $\mathrm{HCl}$ assay gave much higher values of 4.7 and $3.9 \mathrm{~g} / 100 \mathrm{~g}$ dry weight for these samples. However, when the ensiled sample was first treated with $\mathrm{NaOH}$ and then thiolyzed, proanthocyanidin content increased from $0.4 \mathrm{~g}$ to $2.2 \mathrm{~g} / 100 \mathrm{~g}$ dry weight in the silage. It can also be seen that the sum of acetone/water extractable $(0.4 \mathrm{~g} / 100 \mathrm{~g}$ dry weight) plus residual (1.9 $\mathrm{g} / 100 \mathrm{~g}$ dry weight) proanthocyanidins was comparable to the directly determined result in the silage ( $2.3 \mathrm{~g}$ vs $2.2 \mathrm{~g} / 100 \mathrm{~g}$ dry weight). $\mathrm{NaOH}$ facilitated the release of prodelphinidins $(69.9 \%$ with $\mathrm{NaOH}$ vs $50.1 \%$ without 
272 values of 9.1 vs 4.4) from the silage and a similar trend can be seen in the $\mathrm{NaOH}-$

273 treated plant residue. Table 2 shows that these changes stemmed from a 10 -fold

274 increase in the concentration of epigallocatechin (2) extension units (1.2 vs 12.7

$275 \mathrm{mg} / \mathrm{g}$ ) and a 2- to 4-fold increase in all other flavan-3-ol concentrations. Taken

276 together, the results demonstrate that $\mathrm{NaOH}$ facilitated especially the release of

277 larger prodelphinidins from the residue, and that ensiling profoundly reduced

278 proanthocyanidin extractability. This $\mathrm{NaOH} /$ thiolysis reaction was then also applied

279 to other sainfoin silages, which had proanthocyanidins that had proved completely

280 resistant to thiolysis, and the results are shown in Table 3.

281 Ensiling caused proanthocyanidin contents to fall by $29 \%$ from $3.1 \mathrm{~g}$ in the fresh to $2.2 \mathrm{~g} / 100 \mathrm{~g}$ dry weight in the ensiled sample (Table 1), whereas a loss of $17 \%$ from

$4.7 \mathrm{~g}$ to $3.9 \mathrm{~g} / 100 \mathrm{~g}$ dry weight was found with the acetone-butanol- $\mathrm{HCl}$ reagent.

These results are in line with other studies that reported lower proanthocyanidin contents after ensiling. ${ }^{5}$ However, there is also some evidence that ensiling can produce variable results, as others ${ }^{7}$ found no change in proanthocyanidin content when birdsfoot trefoil or sulla were ensiled; although it is worth pointing out that these authors had used an $\mathrm{HCl}$-butanol method, which yields lower total proanthocyanidin contents than the acetone-HCl-butanol method used here. ${ }^{16}$ Ensiling appears to affect mainly extractable proanthocyanidins, which accounted for $81 \%$ in the fresh but for only $18 \%$ in the ensiled samples. This implies that ensiling substantially increased the proportion of residual or bound proanthocyanidins (Table 1) and is in accord with literature data. ${ }^{7,8,21}$ It would appear that $\mathrm{NaOH}$ affected the measured proanthocyanidin content by releasing bound proanthocyanidins from the residue (Tables 1 and 3). 
However, ensiling appears to have caused hardly any changes in the composition of the assayable proanthocyanidins (Table 2). In agreement with the literature, epigallocatechin (2) and epicatechin (4) extension units accounted for the majority of flavan-3-ols in sainfoin proanthocyanidins ${ }^{22,23}$ and residues contained a higher percentage of prodelphinidins than extracts (Table 1). ${ }^{10}$

Whilst purified proanthocyanidins were readily degraded by $\mathrm{NaOH}$ (Figure 2) and several reaction products (peaks a to g) were detected, there was some evidence that proanthocyanidins in the fresh sample were also degraded by $\mathrm{NaOH}$ (Table 1): measured proanthocyanidin contents changed from $3.1 \mathrm{~g}$ to $2.4 \mathrm{~g} / 100 \mathrm{~g}(P=0.05)$, mean degrees of polymerization from 8.2 to $5.3(P=0.01)$ and the percentages of prodelphinidins from $69 \%$ to $73 \%(P=0.05)$, but inspection of the HPLC-MS chromatograms showed no or only trace amounts of any of the proanthocyanidin degradation products that had been observed with the pure proanthocyanidin fraction. In contrast, we could find no evidence that $\mathrm{NaOH}$ caused depolymerization of ensiled proanthocyanidins, as proanthocyanidins in fresh (by thiolysis) and ensiled sainfoin (by $\mathrm{NaOH}$-thiolysis) had similar mean degrees of polymerization (whole plants: 8.2 vs 9.1; residues: 8.1 vs 8.3 ) and prodelphinidin percentages (whole plants: 69.1 vs $69.9 \%$; residues: 72.0 vs $72.9 \%$ ).

It would appear that in the absence of a $\mathrm{NaOH}$ pre-treatment, benzyl mercaptan reacted mainly with the extractable proanthocyanidins, as the quantities were the same, i.e. $0.4 \mathrm{~g} / 100 \mathrm{~g}$ for the ensiled plant and acetone/water extract (Table 1). Benzyl mercaptan also seemed to react preferentially with procyanidins rather than prodelphinidins in all samples, as shown by the higher procyanidin percentages (31\% in fresh and $50 \%$ in ensiled plants), which were almost identical for the whole plants and the extracts (Table 1). This might be due to the fact that procyanidins 
were more soluble in acetone/water than prodelphinidins in these samples and seems to suggest that proanthocyanidins need to be 'free' in order to react with benzyl mercaptan. An alternative explanation for these procyanidin-prodelphinidin differences could be that interflavanyl links were more difficult to break with benzyl mercaptan in larger than smaller proanthocyanidin polymers as larger polymers in sainfoin tend to be prodelphinidins. ${ }^{10}$

\section{Effect of $\mathrm{NaOH}$ on Other Polyphenolic Compounds in Ensiled Sainfoin. Several} flavonoids ${ }^{22,24}$ and isoflavones ${ }^{25}$ were also detected in the silage and tentatively assigned based on their $m / z$ values (Figures 1 and 3 ). They were quantitated using authentic standards (provided there were no co-eluting impurities) and this showed that $\mathrm{NaOH}$ treatment reduced the concentrations of some of these compounds by up to $44 \%$ (Figure 3B). The concentration without and with the $\mathrm{NaOH}$ treatment were as follows: rutin (4.5 vs $4.3 \mathrm{mg} / \mathrm{g}$ dry weight), afzelin (1.4 vs $1.1 \mathrm{mg} / \mathrm{g}$ dry weight), quercetin (1.8 vs $1.1 \mathrm{mg} / \mathrm{g}$ dry weight), kaempferol (0.9 vs $0.5 \mathrm{mg} / \mathrm{g}$ dry weight), isorhamnetin ( 0.3 vs $0.2 \mathrm{mg} / \mathrm{g}$ dry weight), formononetin ( $0.10 \mathrm{vs} 0.06 \mathrm{mg} / \mathrm{g}$ dry weight) and afromosin (0.06 vs $0.04 \mathrm{mg} / \mathrm{g}$ dry weight).

\section{On the Nature and Reactivity of Residual Proanthocyanidins in Silage.}

Relatively little is known about the reactions of proanthocyanidins with other plant constituents in processed plant samples. The method of Terrill et al. ${ }^{8}$ distinguishes between extractable and protein-bound proanthocyanidins using solvents designed to dissociate hydrogen bonds and hydrophobic interactions. However, Hagerman ${ }^{26}$ reported that covalent bonds can also be formed between proanthocyanidins and amino acids such as L-lysine and L-cysteine under neutral to alkaline conditions. The 
reaction between proanthocyanidins and the amino group in L-lysine gives rise to $N$ quinoyls or Schiff's bases and the sulfhydryl group of L-cysteine can generate a covalent thioether linkage. Other studies reported oxidative coupling between catechin (3) and L-lysine ${ }^{27}$ and also between thiols in cysteine, glutathione, 3mercaptohexan-1-ol and the A- or B-rings of epigallocatechin gallate (2) or between thiols in peptides and rosmarinic acid. ${ }^{28,29} \mathrm{All}$ of these reactions can take place under slightly acidic conditions, i.e. at a pH of 4 to 6 , and could, therefore, occur during ensiling. ${ }^{30}$ Covalent linkages may prevent reaction with benzyl mercaptan as reported recently for proanthocyanidin-glycosides, which were, however, detected with butanol- $\mathrm{HCl}^{31}$ this could account for the larger proanthocyanidin loss measured by thiolysis (29\%) than by acetone-HCl-butanol (17\%).

Covalent links could also have been generated via proanthocyanidin oxidation by oxidases, which are released upon cell death and remain active during the initial stages of ensiling. ${ }^{32,33}$ Thus, any intermolecular oxidative reactions formed between proanthocyanidins and other cellular components are likely to generate covalent cross linkages that may resist thiolysis. In addition, flavan-3-ols reacting with the carbonyl group in aldehydes could also generate thiolysis-resistant bonds and such flavan-3-ol-aldehyde adducts were reported in wine. ${ }^{34}$ Aldehydes are present in legume silages and result from the degradation of amino acids, organic acids and fatty acids. ${ }^{35}$

Sodium hydroxide $(0.1 \text { to } 10 \mathrm{M} \mathrm{NaOH} \text { under nitrogen for } 30 \text { to } 60 \mathrm{~min})^{36}$ is widely used for releasing phenolics from cell wall carbohydrates that are linked via ester or ether bonds. ${ }^{14,36,37}$ Ensiling may have given rise to enzymatic esterification and ester bonds are the most likely bonds to be hydrolyzed by this short, $15 \mathrm{~min}, 1 \mathrm{M} \mathrm{NaOH}$ treatment at $40^{\circ} \mathrm{C}$, although hydrogen bonds in tannin-protein or tannin- 
371 carbohydrate complexes might also be disrupted. Interestingly, Grabber et al. ${ }^{37}$ successfully incorporated epicatechin (4) into lignin with peroxidase and ester-linked components were subsequently analyzed after hydrolysis with $\mathrm{NaOH}$.

In conclusion, this is the first report of an analytical method capable of characterizing proanthocyanidin contents and composition in an ensiled animal feed. A 15 min pretreatment at $40{ }^{\circ} \mathrm{C}$ with $1 \mathrm{M} \mathrm{NaOH}$ under argon was required to release bound proanthocyanidins and enabled their subsequent analysis by thiolytic degradation. The composition of assayable proanthocyanidins resembled that of the original proanthocyanidins in the fresh plant, but $29 \%$ of the original proanthocyanidins could not be detected by this $\mathrm{NaOH}$-thiolysis treatment and $17 \%$ by the acetone-butanol$\mathrm{HCl}$ reagent. This suggests that fermentation had caused considerable proanthocyanidin losses or structural changes. Ensiling also had a major effect on the extractability of proanthocyanidins and most remained in the silage residue after the acetone/water extraction, i.e. $86 \%$. It would be interesting to explore whether the presence of such unextractable proanthocyanidins may be responsible for the enhanced anthelmintic (deworming) activities, which have been observed when feeding ensiled proanthocyanidin-containing samples. ${ }^{38,39}$ We venture to hypothesize that these bound proanthocyanidins may act post-ruminally in the form of 'slowrelease' compounds against parasitic nematodes in the small intestine, although this will require further research.

\section{FUNDING SOURCE}

393 Financial support was provided by the European Commission (Marie Curie Initial Training Network, “LegumePlus”, PITN-GA-2011-289377). 
NOTE

397 The authors declare no competing financial interest.

398

\section{AUTHORS CONTRIBUTION}

400

AR and IMH designed the study. AGB and MG produced sainfoin silage samples from Posieux (Switzerland) under the supervision of FDM and GB. GC produced silages samples from Theix (France) under the supervision of VN. AR carried out the study and analyzed the data. AR co-wrote the manuscript with IMH. CD contributed to analysis of proanthocyanidins. All authors critically read and approved the final manuscript.

\section{Supporting Information}

Analysis of variance used to assess effects of reaction times and $\mathrm{NaOH}$ concentrations on the proanthocyanidin parameters (Table S1). Thiolytic degradation of proanthocyanidins with benzyl mercaptan (Figure S1). Changes in proanthocyanidin contents and mean degrees of polymerization with different $\mathrm{NaOH}$ concentrations over a 60 minute time period (Figure S2). Changes in molar percentages of prodelphinidins and trans flavan-3-ols with different $\mathrm{NaOH}$ concentrations over a 60 minute time period (Figure S3). Changes in the contents of terminal flavan-3-ol units with different $\mathrm{NaOH}$ concentrations over a 60 minute time period (Figure S4). Changes in the contents of extension flavan-3-ol units with different $\mathrm{NaOH}$ concentrations over a 60 minute time period (Figure S5). Tentative assignments of several reaction products after treating a pure sainfoin proanthocyanidin fraction with $\mathrm{NaOH}$ and benzylmercaptan (Figure S6). This material is available free of charge via the Internet at http://pubs.acs.org. 


\section{REFERENCES}

424

425

426

427

428

429

430

431

432

433

434

435

436

437

438

439

440

441

442

443

444

445

1. Hayot Carbonero, C.; Mueller-Harvey, I.; Brown, T. A.; Smith, L. Sainfoin

(Onobrychis viciifolia): a beneficial forage legume. Plant Genet. Resour. 2011, 9, 7085.

2. Mueller-Harvey, I. "Holy Hay" - re-inventing a traditional animal feed. Biologist. 2009, 56, 1-6.

3. Hoste, H.; Martinez-Ortiz-De-Montellano, C.; Manolaraki, F.; Brunet, S.; OjedaRobertos, N.; Fourquaux, I.; Torres-Acosta, J. F. J.; Sandoval-Castro, C. A. Direct and indirect effects of bioactive tannin-rich tropical and temperate legumes against nematode infections. Vet. Parasitol. 2012, 186, 18-27.

4. Saratsis, A.; Regos, I.; Tzanidakis, N.; Voutzourakis, N.; Stefanakis, A.; Treuter, D.; Joachim, A.; Sotiraki, S. In vivo and in vitro efficacy of sainfoin (Onobrychis viciifolia) against Eimeria spp in lambs. Vet. Parasitol. 2012, 188, 1-9.

5. Wang, Y.; McAllister, T. A.; Acharya, S. Condensed tannins in sainfoin: composition, concentration, and effects on nutritive and feeding value of sainfoin forage. Crop Sci. 2015, 55, 13-22.

6. Lorenz, M. M.; Eriksson, T.; Udén, P. Effect of wilting, silage additive, PEG treatment and tannin content on the distribution of $\mathrm{N}$-fractions after ensiling of three different sainfoin (Onobrychis viciifolia) varieties. Grass Forage Sci. 2010, 65, 175184.

7. Minnée, E. M. K.; Woodward, S. L.; Waghorn, G. C.; Laboyrie, P. G. The effect of ensiling forage legumes on condensed tannins. Agronomy N.Z. 2002, 32, 117-119.
8. Terrill, T. H.; Mosjidis, J. A.; Moore,
D. A.; Shaik, S. A.; Miller, J. E.; Burke, J. M.; 
Muir, J. P.; Wolfe, R. Effect of pelleting on efficacy of Sericea lespedeza hay as a natural dewormer in goats. Vet. Parasitol. 2007, 146, 117-122.

9. Copani, G.; Ginane, C.; Le Morvan, A.; Niderkorn, V. Bioactive forage legumes as a strategy to improve silage quality and minimise nitrogenous losses. Anim. Prod. Sci. 2014, 54, 1826-1829.

10. Gea, A.; Stringano, E.; Brown, R. H.; Mueller-Harvey, I. In situ analysis and structural elucidation of sainfoin (Onobrychis viciifolia) tannins for high-throughput germplasm screening. J. Agric. Food Chem. 2011, 59, 495-503.

11. Scharenberg, A.; Arrigo, Y.; Gutzwiller, A.; Wyss, U.; Hess, H. D.; Kreuzer, M.;

Dohme, F. Effect of feeding dehydrated and ensiled tanniferous sainfoin (Onobrychis viciifolia) on nitrogen and mineral digestion and metabolism of lambs. Arch. Anim.

Nutr. 2007, 61, 390-405.

12. Arrigo; Y; Dohme; F. Sainfoin versus alfalfa as supplements for grazing cows. Revue Suisse Agric. 2009, 41, 283-288.

13. White, B. L.; Howard, L. R.; Prior, R. L. Release of bound procyanidins from cranberry pomace by alkaline hydrolysis. J. Agric. Food Chem. 2010, 58, 75727579.

14. Wang, W.; Guo, J.; Zhang, J.; Peng, J.; Liu, T.; Xin, Z. Isolation, identification and antioxidant activity of bound phenolic compounds present in rice bran. Food Chemistry. 2015, 171, 40-49.

15. Monente, C.; Ludwig, I. A.; Irigoyen, A.; De Peña, M. P.; Cid, C. Assessment of total (free and bound) phenolic compounds in spent coffee extracts. J. Agric. Food Chem. 2015, 63, 4327-4334. analysis of procyanidin- and prodelphinidin-based condensed tannins in Lotus 
species by the butanol-HCl-iron assay. J. Agric. Food Chem. 2013, 61, 2669-2678.

472

473

474

475

476

477

478

479

480

481

482

483

484

485

486

487

488

489

490

491

492

493

494

495

17. Krook, M. A.; Hagerman, A. E. Stability of polyphenols: Epigallocatechin gallate and pentagalloyl glucose in a simulated digestive system. Food Res. Int. 2012, 49, 112-116.

18. Laks, P. E.; Hemingway, R. W. Condensed tannins: base-catalysed reactions of polymeric procyanidins with toluene- $\alpha$-thiol. Lability of the interflavanoid bond and pyran ring. J. Chem. Soc., Perkin Trans. 1. 1987, 465-470.

19. Shii, T.; Tanaka, T.; Watarumi, S.; Matsuo, Y.; Miyata, Y.; Tamaya, K.; Tamaru, S.; Tanaka, K.; Matsui, T.; Kouno, I. Polyphenol composition of a functional fermented tea obtained by tea-rolling processing of green tea and loquat leaves. J. Agric. Food Chem. 2011, 59, 7253-7260.

20. Skrzypczak-Jankun, E.; Zhou, K.; Jankun, J. Inhibition of lipoxygenase by (-)epigallocatechin gallate: X-ray analysis at 2.1 $\AA$ reveals degradation of EGCG and shows soybean LOX-3 complex with EGC instead. Int. J. Mol. Med. 2003, 12, 415422.

21. Lorenz, M. M.; Udén, P. Influence of formic acid and dry matter on protein degradation in the tanniniferous legume sainfoin. Anim. Feed Sci. Technol. 2011, $164,217-224$.

22. Marais, J. P. J.; Mueller-Harvey, I.; Brandt, E. V.; Ferreira, D. Polyphenols, condensed tannins and other natural products in Onobrychis viciifolia (sainfoin). J. Agric. Food Chem. 2000, 48, 3440-3447.

23. Stringano, E.; Carbonero, C. H.; Smith, L. M. J.; Brown, R. H.; Mueller-Harvey, I. Proanthocyanidin diversity in the EU 'HealthyHay' sainfoin (Onobrychis viciifolia) germplasm collection. Phytochemistry. 2012, 77, 197-208.

24. Regos, I.; Urbanella, A.; Treutter, D. Identification and quantification of phenolic 
compounds from the forage legume sainfoin (Onobrychis viciifolia). J. Agric. Food

497 Chem. 2009, 57, 5843-5852.

25. Regos, I.; Treutter, D. Optimization of a high performance liquid chromatography method for the analysis of complex polyphenol mixtures and application for sainfoin extracts (Onobrychis viciifolia). J. Chromatogr. A 2010, 1217, 6169-6177. 26. Hagerman, A. E. Fifty years of polyphenol-protein complexes. Chapter 3 in Recent Advances in Polyphenol Research, First edition, Cheynier, V.; SarniManchado, P.; Quideau, S., Eds; Publisher: Wiley \& Sons, Oxford, UK, 2012; Vol. no. 3, pp. 71-97.

27. You, J.; Luo, Y.; Wu, J. Conjugation of ovotransferrin with catechin shows improved antioxidant activity. J. Agric. Food Chem. 2014, 62, 2581-2587. 28. Unnadkat, N. R.; Elias, R. J. Oxidative stability of (-)-epigallocatechin gallate in the presence of thiols. J. Agric. Food Chem. 2012, 60, 10815-10821.

29. Tang, C. B.; Zhang, W. G.; Dai, C.; Li, H. X.; Xu, X. I.; Zhou, G. H. Identification and quantification of adducts between oxidized rosmarinic acid and thiol compounds by UHPLC-LTQ-Orbitrap and MALDI-TOF/TOF tandem mass spectrometry. J. Agric. Food Chem. 2015, 63, 902-911.

30. Chen, Y.; Hagerman, A. E. Reaction $\mathrm{pH}$ and protein affect the oxidation products of $\beta$-pentagalloyl glucose. Free Radic. Res. 2005, 39, 117-124. 31. Stringano, E.; Cramer, R.; Hayes, W.; Smith, C.; Gibson, T.; Mueller-Harvey, I. Deciphering the complexity of sainfoin (Onobrychis viciifolia) proanthocyanidins by MALDI-TOF mass spectrometry with a judicious choice of isotope patterns and matrixes. Anal. Chem. 2011, 83, 4147-4153. clover with and without polyphenol oxidase (PPO) activity and their role in PPO 
521 activation and inactivation. Grass Forage Sci. 2012, 68, 83-92.

522 33. Thill, J.; Regos, I.; Farag, M. A.; Ahmad, A. F.; Kusek, J.; Castro, A.; Schlangen, K.; Carbonero, C. H.; Gadjev, I. Z.; Smith, L. M. J.; Halbwirth, H.; Treutter, D.; Stich, K. Polyphenol metabolism provides a screening tool for beneficial effects of Onobrychis viciifolia (sainfoin). Phytochemistry. 2012, 82, 67-80.

34. Drinkine, J.; Glories, Y.; Saucier, C. (+)-Catechin-aldehyde condensations: Competition between acetaldehyde and glyoxylic acid. J. Agric. Food Chem. 2005, $53,7552-7558$.

35. Figueiredo, R.; Rodrigues, A.; do Céu Costa, M. Volatile composition of red clover (Trifolium pratense L.) forages in Portugal: The influence of ripening stage and ensilage. Food Chem. 2007, 104, 1445-1453.

36. Westcott, N.D., Chemical studies on the constituents of Linum spp. In Flax-The genus Linum, Muir, A.D.; Westcott, N.D., Eds; Publisher: Taylor \& Francis, New York, US, 2003; pp. 300.

37. Grabber, J. H.; Ress, D.; Ralph, J. Identifying new lignin bioengineering targets: impact of epicatechin, quercetin glycoside, and gallate derivatives on the lignification and fermentation of maize cell walls. J. Agric. Food Chem. 2012, 60, 5152-5160. 38. Kommuru, D. S.; Barker, T.; Desai, S.; Burke, J. M.; Ramsay, A.; Mueller-Harvey, I.; Miller, J. E.; Mosjidis, J. A.; Kamisetti, N.; Terrill, T. H. Use of pelleted sericea lespedeza (Lespedeza cuneata) for natural control of coccidia and gastrointestinal nematodes in weaned goats. Vet. Parasitol. 2014, 204, 191-198.

D. A.; Maurer, V.; Zinsstag, J.; Langhans, W.; Hertzberg, H. Effect of sainfoin (Onobrychis viciifolia) silage and hay on established populations of Haemonchus contortus and Cooperia curticei in lambs. Vet. Parasitol. 2006, 142, 293-300. 


\section{FIGURE CAPTIONS}

Figure 1. Flavan-3-ol monomeric subunits of proanthocyanidins and other phenolics detected in sainfoin silage (dashed numbers, 1' to 10', refer to peak numbers in Figure 3).

Figure 2. HPLC chromatograms after thiolysis of a pure sainfoin proanthocyanidin fraction. A. without $\mathrm{NaOH}$ pre-treatment, B. after $15 \mathrm{~min}$, and C. after 60 min of $\mathrm{NaOH}$ pre-treatment. 1, gallocatechin; 2, epigallocatechin; 3, catechin; 4, epicatechin; 5; internal standard (taxifolin); 6, 3,4-trans-gallocatechin-benzyl mercaptan; 7, 3,4-cis-gallocatechin-benzyl mercaptan; 8, epigallocatechin-benzyl mercaptan; 9, 3,4-trans-catechin-benzyl mercaptan; 10, 3,4-cis-catechin-benzyl mercaptan; 11, epicatechin-benzyl mercaptan; *, unidentified peaks.

Figure 3. HPLC chromatograms after in situ thiolysis of proanthocyanidins in ensiled sainfoin without $(A)$ and with $(B) \mathrm{NaOH}$ pre-treatment $\left(1 \mathrm{M} \mathrm{NaOH}, 40^{\circ} \mathrm{C}, 15 \mathrm{~min}\right) .2$, epigallocatechin; 3, catechin; 4, epicatechin; 5, internal standard (taxifolin); 7, 3,4cis-gallocatechin-benzyl mercaptan; 8, epigallocatechin-benzyl mercaptan; 9, 3,4trans_catechin-benzyl mercaptan; 10, 3,4-cis_catechin-benzyl mercaptan; 11, epicatechin-benzyl mercaptan; *, unidentified compound; $\mathbf{1}^{\prime}$, coumaric acid glycoside; 2', rutin; 3', coumaric acid; 4', afzelin; 5', isorhamnetin-rutinoside; 6', quercetin; 7', kaempferol; 8', isorhamnetin; 9', formononetin; 10', afromosin. 
Table 1. Proanthocyanidin Contents and Compositions of Fresh/Freeze-Dried and Ensiled Sainfoin after Thiolysis in the Absence and Presence of a $\mathrm{NaOH}\left(1 \mathrm{M}, 40^{\circ} \mathrm{C}, 15 \mathrm{~min}\right)$ Pretreatment (SD in parenthesis, $\mathrm{n}=3$ ).

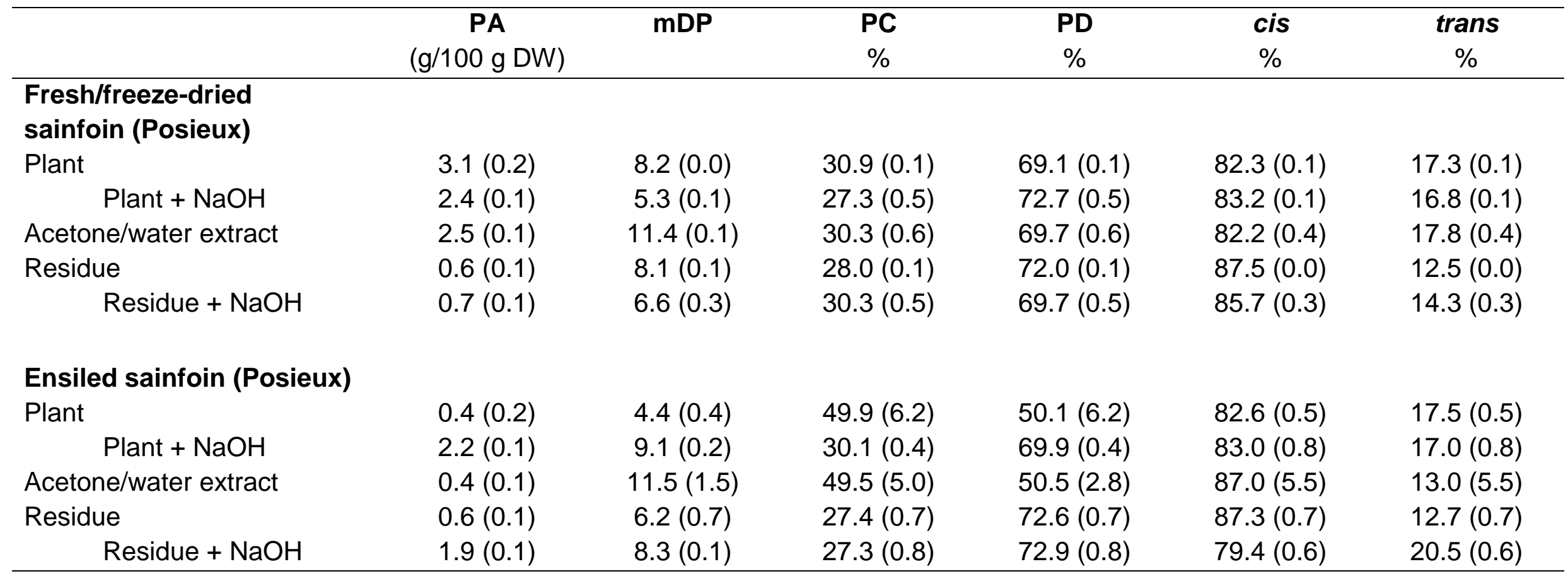

cis: molar percentage of epicatechin plus epigallocatechin subunits; DW: dry weight; mDP: mean degree of polymerization; PA: proanthocyanidins; PC: procyanidins (molar percentage of catechin plus epicatechin subunits); PD: prodelphinidins (molar percentage of gallocatechin plus epigallocatechin subunits); SD: standard deviation; trans: molar percentage of catechin plus gallocatechin subunits. 
Table 2. Concentrations of Flavan-3-ol Terminal and Extension Units (mg flavan-3-ol/g DW) and Relative Molar Percentages (\%) in Fresh/Freeze-Dried and Ensiled Sainfoin after Thiolysis in the Absence and Presence of a $\mathrm{NaOH}\left(1 \mathrm{M}, 40{ }^{\circ} \mathrm{C}, 15 \mathrm{~min}\right)$ Pretreatment (SD in parentheses, $n=3$ ).

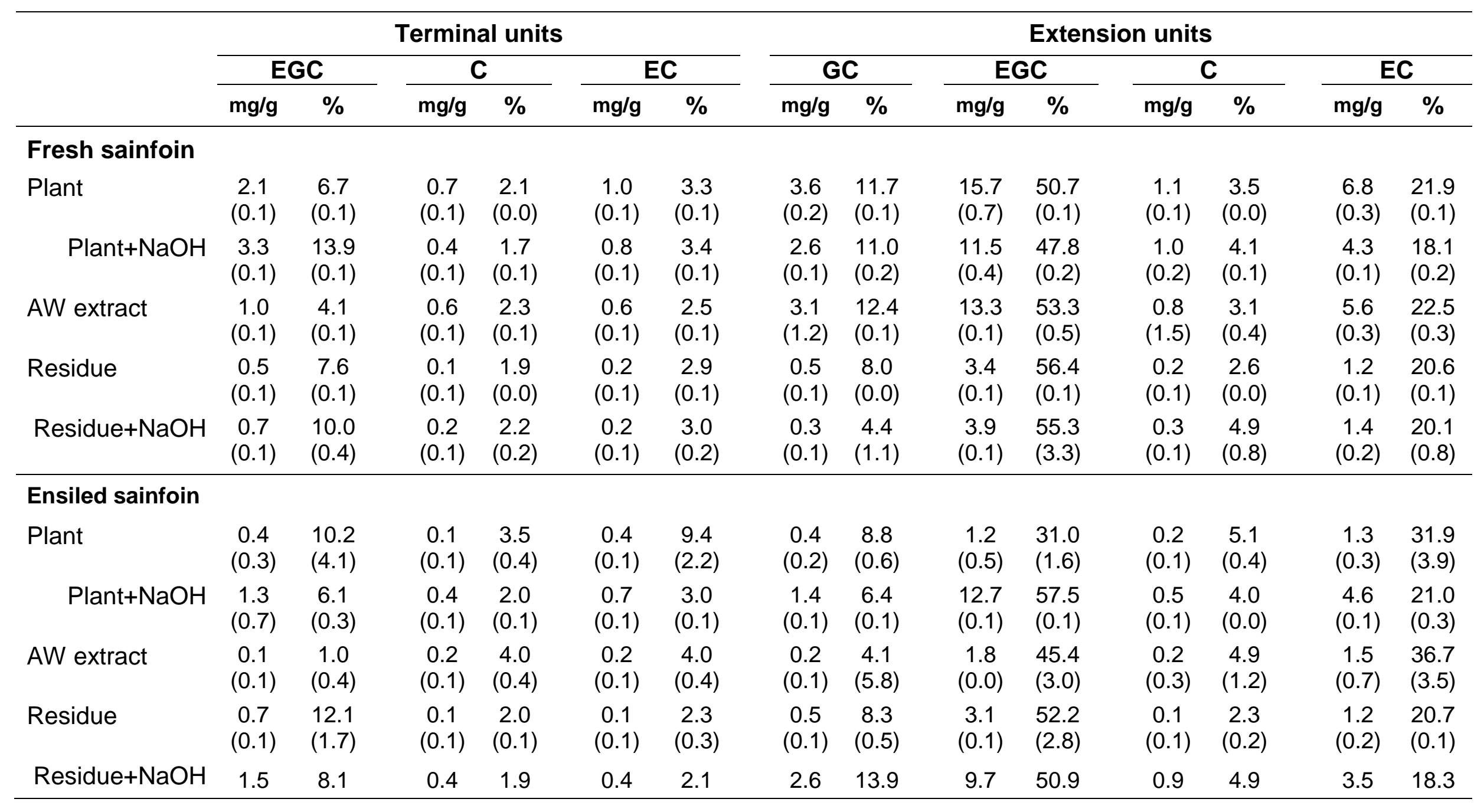


AW: acetone-water; C: catechin; DW: dry weight of plant material; EC: epicatechin; EGC: epigallocatechin; GC: gallocatechin; SD: standard deviation. 
Table 3. Analysis of Thiolysis-Resistant Sainfoin Silages from Theix by the Acetone-Butanol-HCl $(\mathrm{ABH})$ and the Thiolysis Assays in the Absence and Presence of the $\mathrm{NaOH}$ Pretreatment (SD in parentheses, $\mathrm{n}=3$ ).

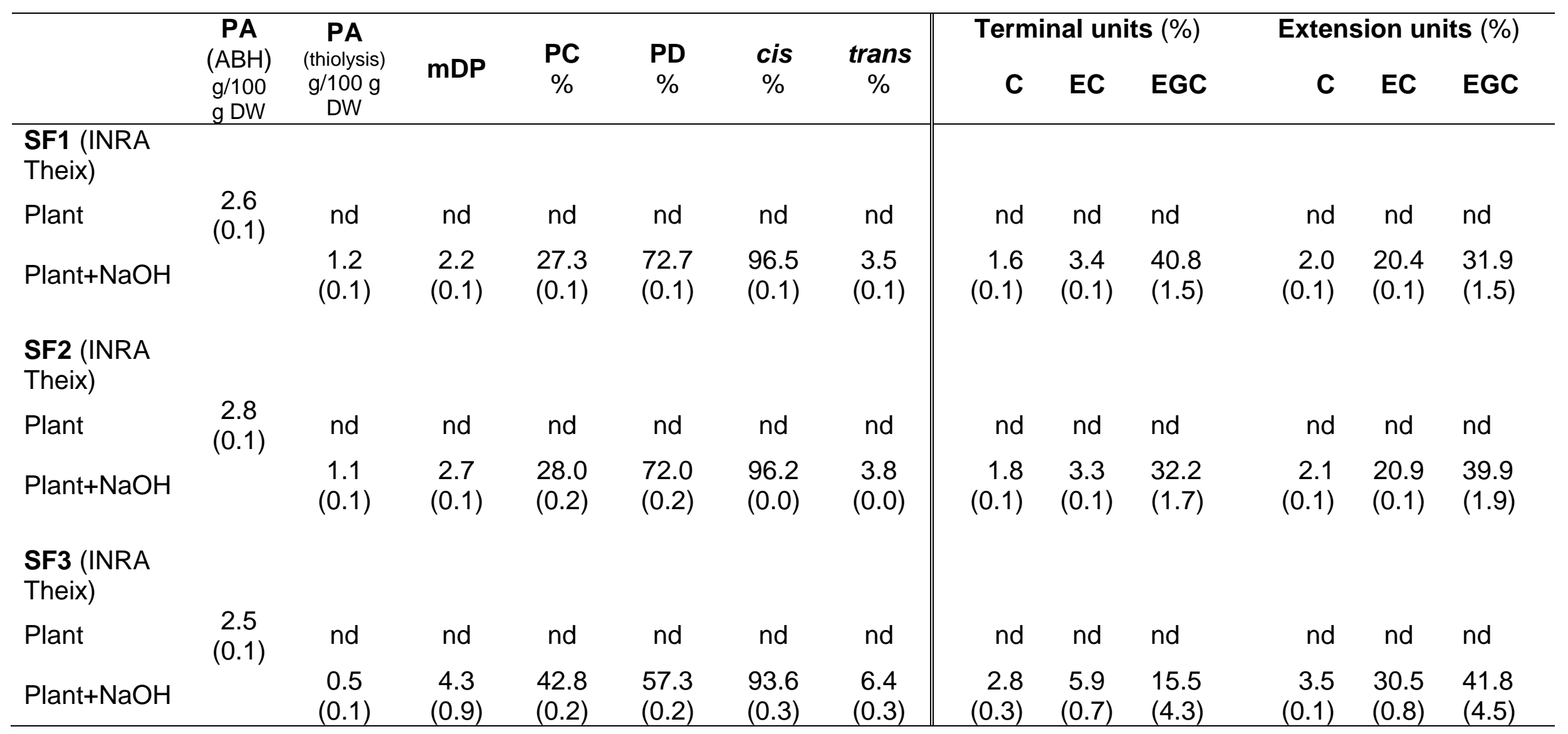

\%: relative molar percentages; C: catechin; cis: epicatechin plus epigallocatechin subunits; DW: dry weight; EC: epicatechin; EGC: epigallocatechin; mDP: mean degree of polymerization; nd: none detected; PA: proanthocyanidins; PC: procyanidins (catechin plus 
epicatechin subunits); PD: prodelphinidins (gallocatechin plus epigallocatechin subunits); SD: standard deviation; trans: catechin plus gallocatechin subunits. 
<smiles>[R2]C1([R2])Cc2c(O)cc(O)cc2O[C@H]1c1cc(O)c(O)c(O)c1</smiles>

1, $\mathrm{R}_{1}=\mathrm{H}, \mathrm{R}_{2}=\mathrm{OH}$, Gallocatechin (a trans-flavan-3-ol)

2, $\mathrm{R}_{1}=\mathrm{OH}, \mathrm{R}_{2}=\mathrm{H}$, Epigallocatechin (a cis-flavan-3-ol)<smiles>[R2]C1([R2])Cc2c(O)cc(O)cc2O[C@H]1c1ccc(O)c(O)c1</smiles>

3, $\mathrm{R}_{1}=\mathrm{H}, \mathrm{R}_{2}=\mathrm{OH}$, Catechin (a trans-flavan-3-ol) $4, \mathrm{R}_{1}=\mathrm{OH}, \mathrm{R}_{2}=\mathrm{H}$, Epicatechin (a cis-flavan-3-ol)

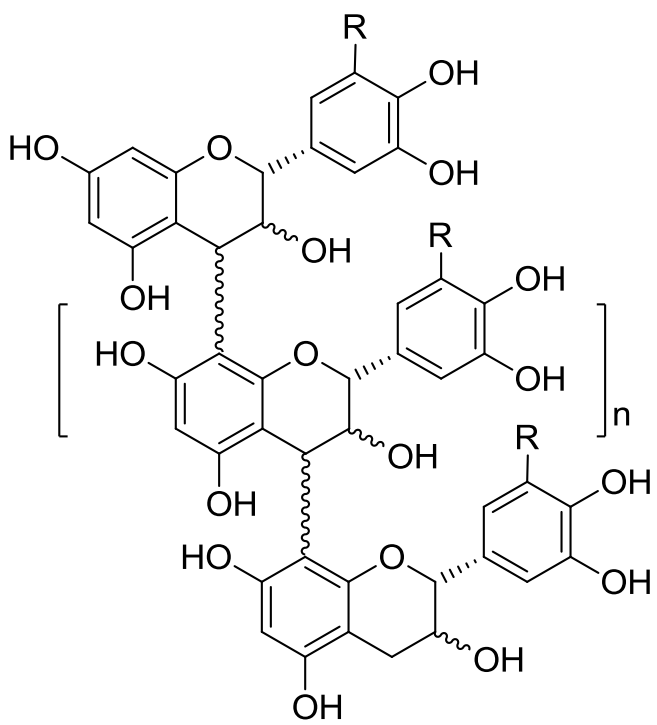

Example of proanthocyanidins: $\mathrm{R}=\mathrm{H}$, procyanidins $\mathrm{R}=\mathrm{OH}$, prodelphinidins<smiles>[R]Oc1ccc(/C=C/C(=O)O)cc1</smiles>

$1^{\prime}, \mathrm{R}=$ hexoside, Coumaroyl-O-glycoside $3^{\prime}, \mathrm{R}=\mathrm{H}$, Coumaric acid<smiles>[R]c1cc2c(=O)c(-c3ccc(OC)cc3)coc2cc1O</smiles>

9', $\mathrm{R}=\mathrm{H}$, Formononetin 10', $\mathrm{R}=\mathrm{OCH}_{3}$, Afromosin<smiles>[R]c1cc(-c2oc3cc(O)cc(O)c3c(=O)c2[R])ccc1O</smiles>

2', $\mathrm{R}_{1}=\mathrm{OH}, \mathrm{R}_{2}=$ O-rutinoside, Rutin $4^{\prime}, \mathrm{R}_{1}=\mathrm{H}, \mathrm{R}_{2}=$ O-rhamnoside, Afzelin $\mathbf{5}^{\prime}, \mathrm{R}_{1}=\mathrm{OCH}_{3}, \mathrm{R}_{2}=\mathrm{O}$-rutinoside, Isorhamnetin-rutinoside $6^{\prime}, \mathrm{R}_{1}=\mathrm{OH}, \mathrm{R}_{2}=\mathrm{OH}$, Quercetin 7', $\mathrm{R}_{1}=\mathrm{H}, \mathrm{R}_{2}=\mathrm{OH}$, Kaempferol 8', $\mathrm{R}_{1}=\mathrm{OCH}_{3}, \mathrm{R}_{2}=\mathrm{OH}$, Isorhamnetin

\section{Figure 1}



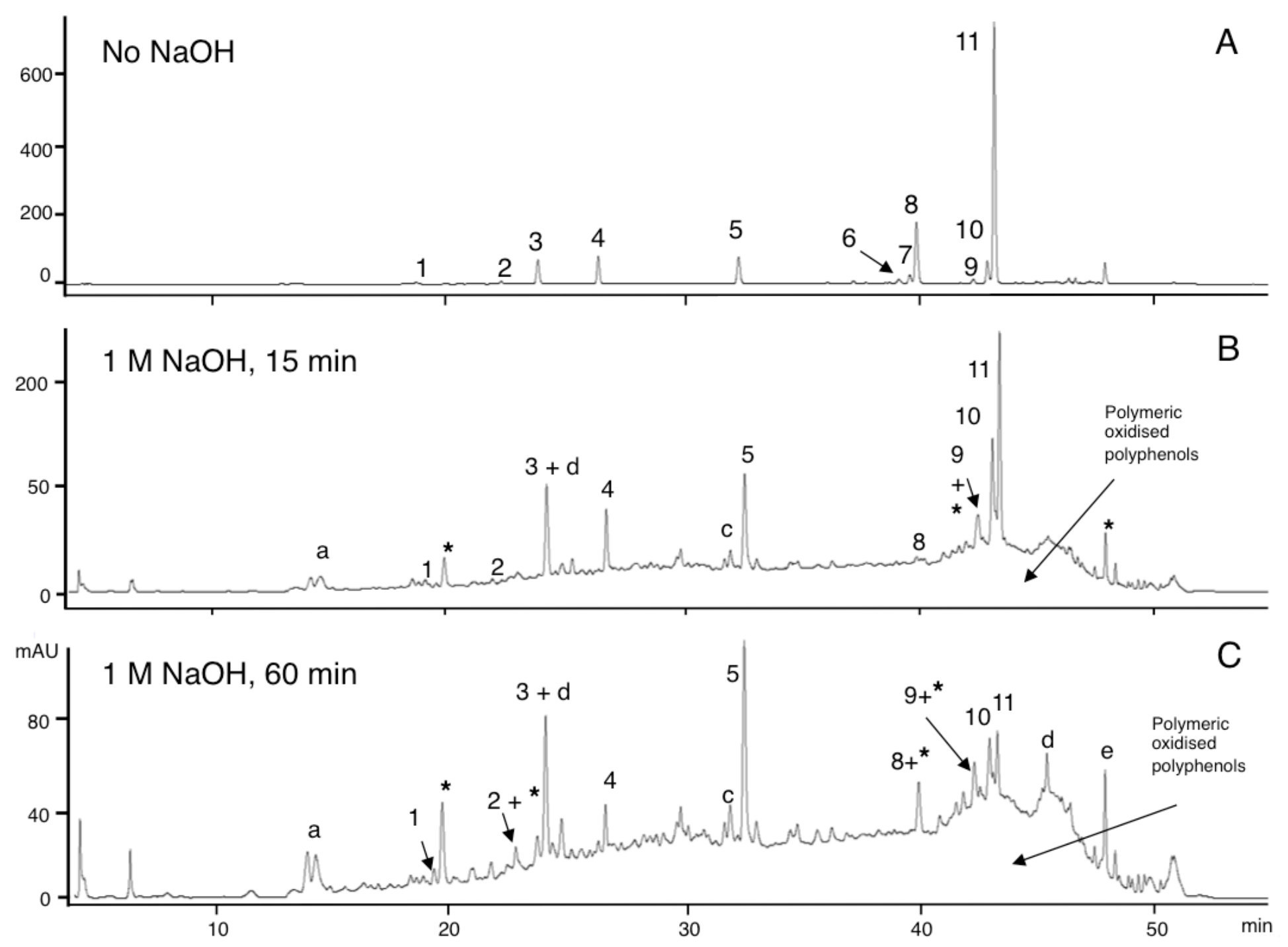

Figure 2 


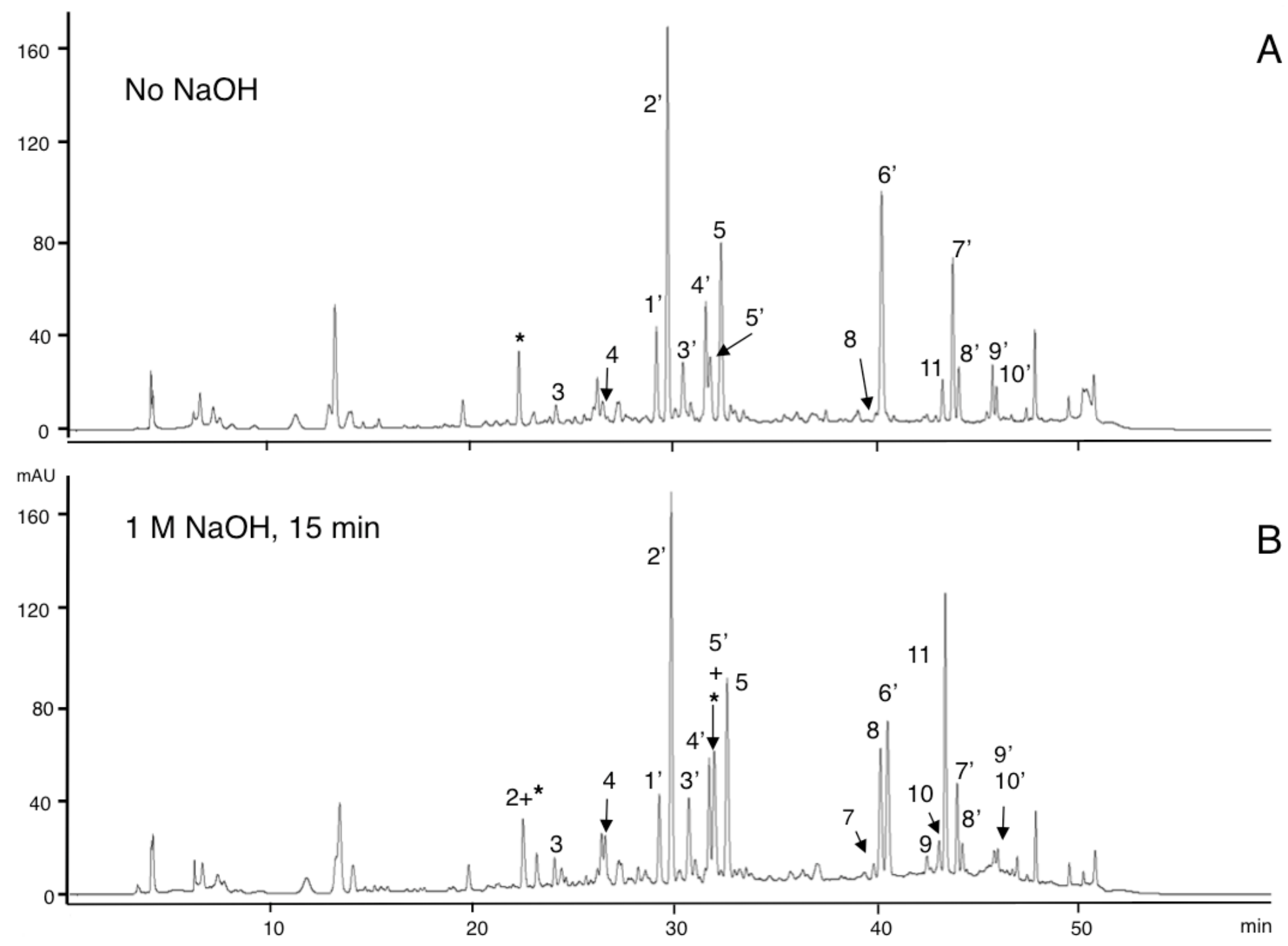

Figure 3 
Table of Contents Graphic

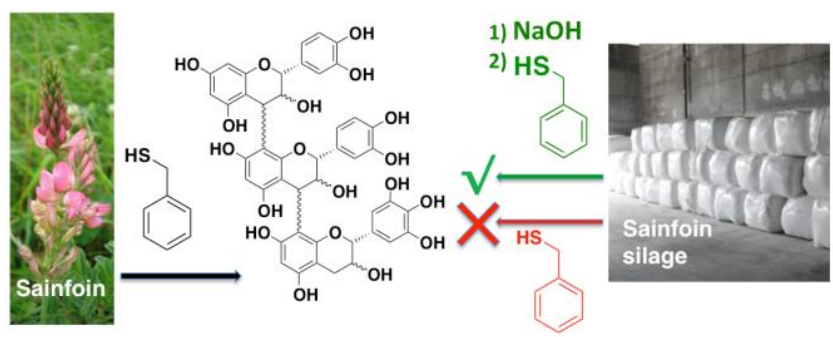

